\title{
THE EFFECT OF ARTERIAL BLOOD SAMPLING SITES ON BLOOD GASES AND ACID-BASE BALANCE PARAMETERS IN CALVES
}

\author{
O. NAGY ${ }^{*}$, G. KovÁČ, H. SEIDEL and T. WeISSOVÁ \\ Department of Internal Diseases of Ruminants and Swine, University of Veterinary \\ Medicine, 04181 Košice, Slovak Republic
}

(Received July 7, 2000; accepted February 8, 2001)

\begin{abstract}
In 21 healthy calves, 1-6 months old, the interrelationship and comparability of acid-base balance variables $\left(\mathrm{pH}, \mathrm{HCO}_{3}^{-}, \mathrm{BE}\right)$ and blood gases $\left(\mathrm{pCO}_{2}\right.$, $\mathrm{pO}_{2}$, and sat $-\mathrm{O}_{2}$ ) were evaluated in arterial blood collected from a larger, centrally localised (the $a$. axillaris) and a smaller peripheral artery (the a. auricularis caudalis). Sampling was done by direct puncture of the vessels without local anaesthesia. Except for blood $\mathrm{pH}$, significant differences were observed in the average values of $\mathrm{pCO}_{2}, \mathrm{pO}_{2}, \mathrm{HCO}_{3}{ }^{-}$, sat- $\mathrm{O}_{2}(\mathrm{P}<0.001)$, and $\mathrm{BE}(\mathrm{P}<0.05)$. Analyses of blood from the axillaris showed higher $\mathrm{pH}, \mathrm{pO}_{2}$, and sat- $\mathrm{O}_{2}$ values, and lower $\mathrm{pCO}_{2}, \mathrm{HCO}_{3}^{-}$, and $\mathrm{BE}$ values compared with that from the a. auricularis caudalis. Despite statistically significant differences between some variables, in all indices high and significant correlation relationships were recorded $(\mathrm{R}=0.928-0.961$; $\mathrm{P}<0.001)$. Therefore, from the biological and clinical point of view, these differences are unimportant and the presented method of peripheral arterial blood sampling can be considered suitable for evaluating blood gases and acid-base status.
\end{abstract}

Key words: Calves, arterial blood, acid-base balance, blood gases

Arterial or arterialised blood is used for the evaluation of acid-base balance and blood gases, especially in human medicine. This examination enables the simultaneous assessment of both metabolic and respiratory compartments and, in case of disorder in any of these compartments, the degree of compensatory response of its counterpart. Analyses of arterial blood are less frequent in veterinary medicine, partly because of the more demanding sampling techniques in animals. Therefore, several authors have investigated suitable sites and techniques for collection of arterial blood in animals, especially in dogs (Feigl and D'Alecy, 1972; Quandt et al., 1991) and horses (Lieske et al., 1981; Deegen, 1983). In cattle, unlike other species, several arteries have been used (Table 1). These arteries can be divided into larger ones - central, localised nearer to the heart, and smaller - peripheral, more distant from the heart. However, only some of them proved to be suitable for the direct puncture of the vessel in routine

*Corresponding author; E-mail: onagy@uvm.sk; Fax: +421 (95) 6323666 
practice. There are several reports on the reference values of acid-base balance variables and blood gases obtained by analyses of blood from different arteries, localised both centrally and peripherally, in healthy cattle. In addition to the well-known differences in acid-base variables and blood gases between arterial and venous blood (Naito and Murakami, 1982; Nagy et al., 1994), Collie (1991) suggested the possible existence of differences between results in arterial blood depending on the localisation of the arteries. Such differences were also reported for venous blood by Bajcsy et al. (1999) who investigated indices of acid-base balance in the blood collected from several different veins.

Following previous results and experiences with arterial blood collection from the $a$. axillaris and a auricularis caudalis in calves (Nagy et al., 1999), this work was aimed at evaluating the differences in acid-base variables and blood gases obtained by analyses of blood from a peripheral vessel - the a. auricularis caudalis and from a more central artery - the a. axillaris, as well as their use in clinical diagnosis. Moreover, if there are differences, there is a question as to which variables differ and whether or not these differences are significant. Besides others, we chose this study because of some controversial literary data (Fischer et al., 1980; Oakley et al., 1980; Gustin et al., 1988). In cattle, the need for the collection of arterial blood from the periphery is frequently the result of the poor accessibility of large central arteries (such as the $a$. brachialis and $a$. axillaris) in older animals. Knowledge of the interrelations of these variables within the course of the arterial bloodstream would facilitate the proper choice of sampling sites in relation to the examinations required.

\section{Material and methods}

Sampling of arterial blood was done in 21 healthy calves (Slovak and White-Black spotted breeds, and their crossbreds) 1-6 months old. The animals were housed individually at the Clinic of Internal Diseases of Ruminants and Swine. They were fed hay and concentrates with free access to drinking water.

Arterial blood was collected from a large central artery - the a. axillaris, and a smaller peripheral artery - the a. auricularis caudalis (medial branch). Samplings were done one immediately after another - first from the a auricularis caudalis and then from the a. axillaris. Before collection of peripheral blood, the convex side of the auricle over the course of the medial branch of the artery was shaved and disinfected (Fig. 1). The a. axillaris was punctured at the base of neck, at the beginning of the jugular groove (Fig. 2). At this site the artery emerges from the thoracic cavity, turns around the 1st rib, and runs caudoventrally towards the medial side of the foreleg. The calves were restrained in the usual way with the help of one man ensuing minimal stress to the animal. Arteries were punctured with disposable needles (G 21) without local anaesthesia. 
EFFECT OF ARTERIAL BLOOD SAMPLING SITES ON BLOOD PARAMETERS IN CALVES

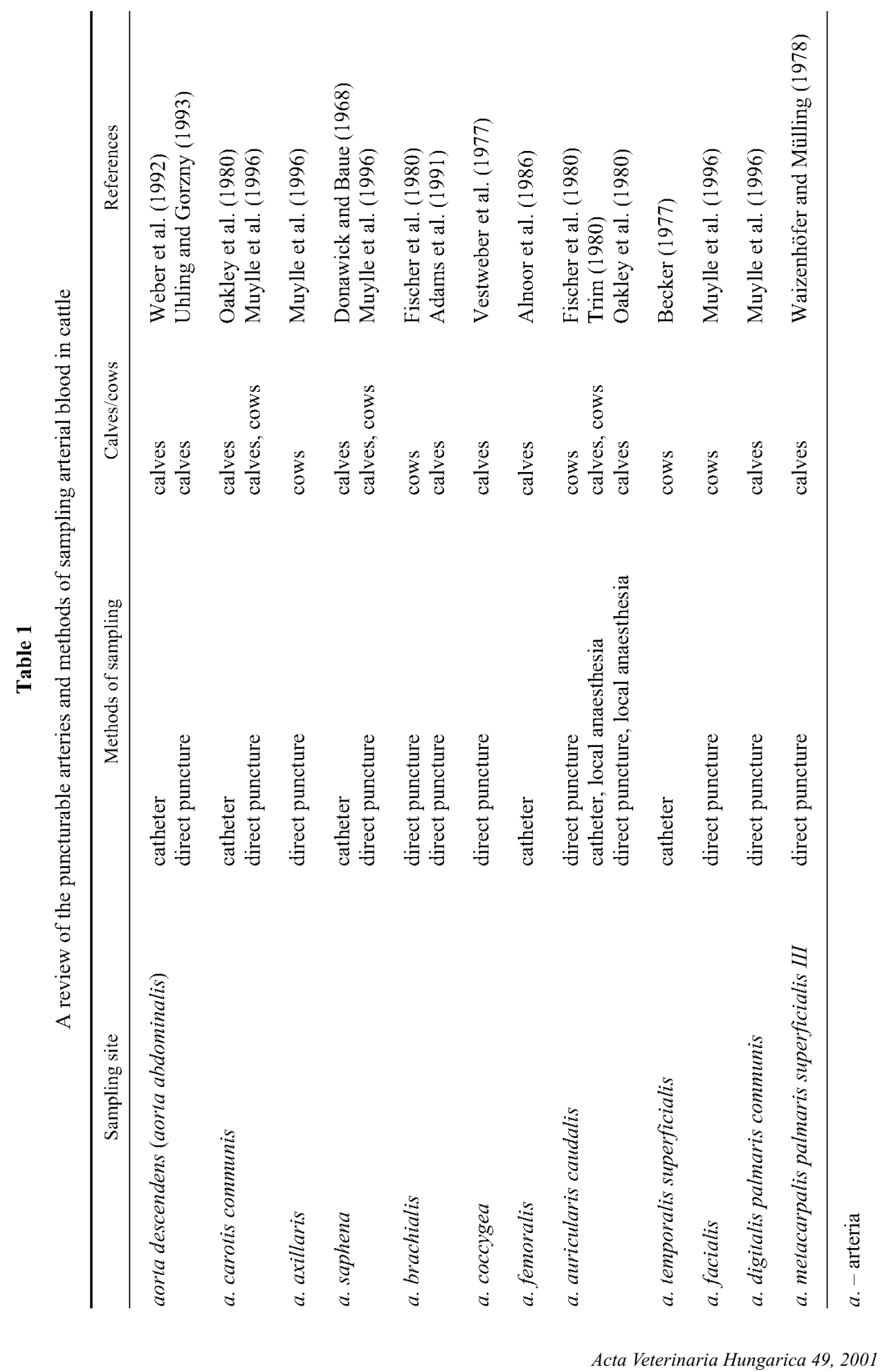


Blood was collected into heparinised glass capillaries (D 551/20/150, $200 \mu$, Radiometer Copenhagen). Paired samples were collected from both sites, stored in ice, and analysed within 30 min of collection. The samples were analysed by an automatic analyser $\mathrm{ABL}_{4}$ (Radiometer Copenhagen) at $37^{\circ} \mathrm{C}$. The following acid-base balance variables and blood gases were evaluated: $\mathrm{pH}$, actual bicarbonate concentration $\left(\mathrm{HCO}_{3}{ }^{-}\right)$, base excess (BE), the partial pressure of oxygen $\left(\mathrm{pO}_{2}\right)$, the partial pressure of carbon dioxide $\left(\mathrm{pCO}_{2}\right)$, and the saturation of haemoglobin with oxygen (sat- $\mathrm{O}_{2}$ ).

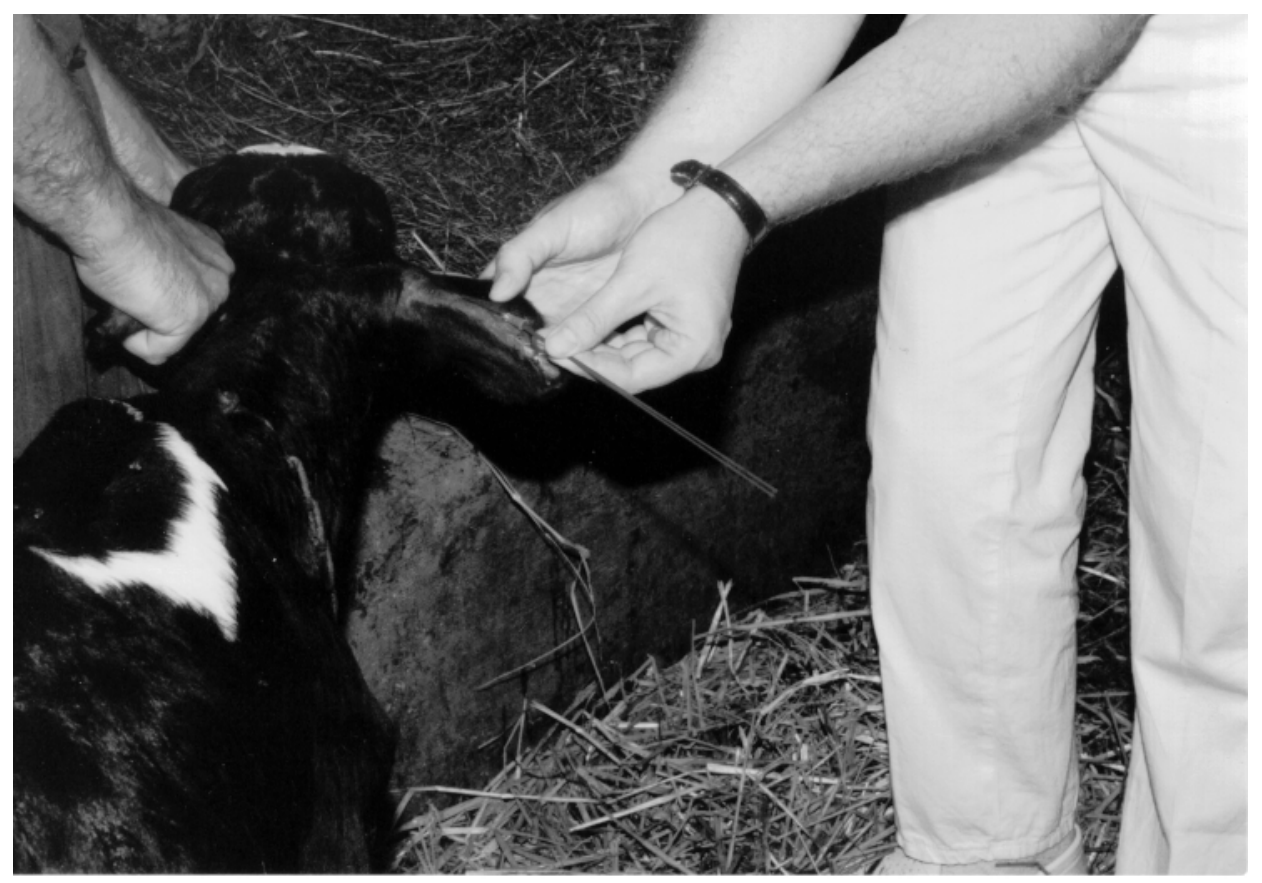

Fig. 1. Arterial blood sampling from the a. auricularis caudalis into capillaries in a one-monthold calf

Results are expressed as mean \pm standard deviation for each parameter and site of sampling. The significance of differences was assessed by paired $t$-test. Relationships between sampling sites, their significance $(\mathrm{P})$, and linear regressions were calculated including Pearson (R) correlation coefficients. Statistical analyses were done with Statgraphics programme (STATGRAPHICS, vers.4.0).

\section{Results}

The results obtained from the axillaris and a. auricularis caudalis are presented in Tables 2, 3 and 4. 


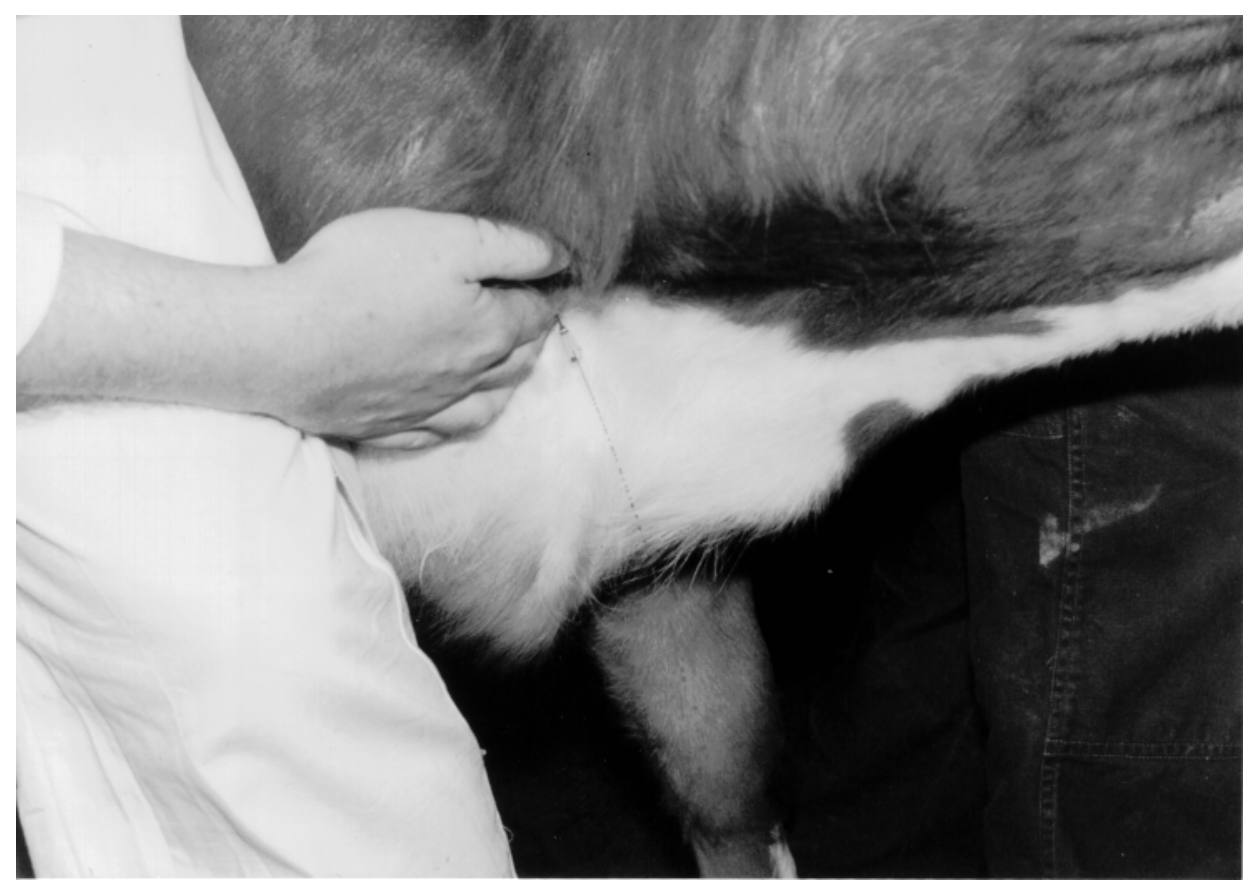

Fig. 2. Puncture of the axillaris in a 5-month-old calf

The results obtained indicate small, but statistically significant differences in mean values obtained from the two sampling sites (Table 2). While no significant differences were recorded in mean $\mathrm{pH}$ values, highly significant differences were observed in the mean values of $\mathrm{pCO}_{2}, \mathrm{pO}_{2}, \mathrm{HCO}_{3}^{-}$, and sat- $\mathrm{O}_{2}(\mathrm{P}<0.001)$, and $\mathrm{BE}(\mathrm{P}<0.05)$. Analyses of blood from the $a$. axillaris showed higher values of $\mathrm{pH}, \mathrm{pO}_{2}$, and sat- $\mathrm{O}_{2}$, and lower $\mathrm{pCO}_{2}, \mathrm{HCO}_{3}{ }^{-}$, and $\mathrm{BE}$ values compared with that from the a. auricularis caudalis. Analyses of difference between the paired values (a. axillaris $-a$. auricularis) of acid-base balance indices and blood gasses calculated from individual values are presented in Table 3 . These results indicate that in most cases blood from the a. axillaris showed higher values of $\mathrm{pH}$, $\mathrm{pO}_{2}$, and sat- $\mathrm{O}_{2}$, while the remaining three variables $\left(\mathrm{pCO}_{2}, \mathrm{HCO}_{3}^{-}\right.$, and $\left.\mathrm{BE}\right)$ were higher in the peripheral arterial blood. In some cases, the same values of $\mathrm{pH}, \mathrm{HCO}_{3}^{-}$, and $\mathrm{BE}$ were recorded regardless of the sampling site. Despite statistically significant differences between some variables, in all indices high and significant correlations were recorded $(\mathrm{R}=0.928-0.961, \mathrm{P}<0.001$, Table 4). The regression equations (y) can be used for the calculation of the expected value in central arterial blood (a. axillaris) from results obtained in peripheral arterial blood (a. auricularis). 
Table 2

Means (x), standard deviations $( \pm \mathrm{SD})$, and differences between average values of acid-base balance variables and blood gases in arterial blood collected from the a. axillaris and a. auricularis in calves $(\mathrm{n}=21)$

\begin{tabular}{lccc}
\hline \multicolumn{1}{c}{ Parameter } & a. axillaris & a. auricularis & Difference \\
\hline $\mathrm{pH}$ & $7.427 \pm 0.03$ & $7.423 \pm 0.03$ & +0.004 \\
$\mathrm{pCO}_{2}(\mathrm{kPa})$ & $5.58 \pm 0.42$ & $5.71 \pm 0.44$ & $-0.13^{\mathrm{c}}$ \\
$\mathrm{pO}_{2}(\mathrm{kPa})$ & $11.63 \pm 1.0$ & $11.28 \pm 1.0$ & $+0.35^{\mathrm{c}}$ \\
$\mathrm{HCO}_{3}{ }^{-}\left(\mathrm{mmol}^{\mathrm{c}} \mathrm{l}^{-1}\right)$ & $27.3 \pm 1.7$ & $27.7 \pm 1.5$ & $-0.4^{\mathrm{c}}$ \\
$\mathrm{BE}\left(\mathrm{mmol}^{-1}\right)$ & $2.9 \pm 1.7$ & $3.1 \pm 1.6$ & $-0.2^{\mathrm{a}}$ \\
$\mathrm{sat}^{-} \mathrm{O}_{2}(\%)$ & $96.6 \pm 0.8$ & $96.3 \pm 0.9$ & $+0.3^{\mathrm{c}}$ \\
\hline
\end{tabular}

a, $\mathrm{c}-$ statistical significance of differences between average values (a: $\mathrm{P}<0.05 ; \mathrm{c}: \mathrm{P}<0.001)$

\section{Table 3}

Analysis of individual differences between acid-base balance variables and blood gases recorded in calves' arterial blood collected from the $a$. axillaris (A) and a. auricularis caudalis (AU)

\begin{tabular}{|c|c|c|c|c|c|}
\hline Parameter & $\begin{array}{c}\mathrm{n}^{1} \\
\mathrm{~A}>\mathrm{AU}\end{array}$ & $\begin{array}{c}\text { max. diff. } \\
\text { A }>\text { AU }\end{array}$ & $\begin{array}{c}\mathrm{n}^{2} \\
\mathrm{~A}<\mathrm{AU}\end{array}$ & $\begin{array}{c}\text { max. diff. } \\
\mathrm{A}<\mathrm{AU}\end{array}$ & $\begin{array}{c}\mathrm{n}^{3} \\
\mathrm{~A}=\mathrm{AU}\end{array}$ \\
\hline $\mathrm{pH}$ & 13 & +0.031 & 5 & -0.019 & 3 \\
\hline $\mathrm{pCO}_{2}(k P a)$ & 2 & +0.17 & 19 & -0.37 & 0 \\
\hline $\mathrm{pO}_{2}(k P a)$ & 19 & +0.74 & 2 & -0.07 & 0 \\
\hline $\mathrm{HCO}_{3}^{-}\left(\right.$mmol. $\left.l^{-1}\right)$ & 3 & +0.5 & 17 & -1.3 & 1 \\
\hline $\mathrm{BE}\left(\mathrm{mmol} . \mathrm{l}^{-1}\right)$ & 5 & +0.6 & 14 & -1.2 & 2 \\
\hline sat- $\mathrm{O}_{2}(\%)$ & 18 & +1.0 & 3 & -0.1 & 0 \\
\hline
\end{tabular}

$\mathrm{n}^{1}$ - number of samples with higher values of corresponding parameter in the blood from the $a$. $a x$ illaris compared with that from the a auricularis caudalis; $\mathrm{n}^{2}-$ number of samples with lower values of corresponding parameter in the blood from the $a$. axillaris compared with that from the $a$. auricularis caudalis; $\mathrm{n}^{3}$ - number of samples with the same values of corresponding parameter in the blood from the $a$. axillaris and the a. auricularis caudalis; max. diff. - maximal difference between the sampling sites

\section{Table 4}

Correlation and regression analyses of acid-base balance parameters and blood gases in arterial blood from a central $-a$. axillaris and a peripheral artery $-a$. auricularis caudalis

\begin{tabular}{llll}
\hline \multicolumn{1}{c}{ Parameter } & \multicolumn{1}{c}{$\mathrm{y}$} & $\mathrm{R}$ & $\mathrm{P}$ \\
\hline $\mathrm{pH}$ & $0.919 \mathrm{x}+0.599$ & 0.928 & $<0.001$ \\
$\mathrm{pO}_{2}$ & $0.980 \mathrm{x}+0.579$ & 0.960 & $<0.001$ \\
$\mathrm{pCO}_{2}$ & $0.914 \mathrm{x}+0.363$ & 0.959 & $<0.001$ \\
$\mathrm{HCO}_{3}^{-}$ & $1.059 \mathrm{x}-2.11$ & 0.961 & $<0.001$ \\
$\mathrm{BE}$ & $1.108 \mathrm{x}-0.336$ & 0.956 & $<0.001$ \\
sat-O & $0.884 \mathrm{x}+11.5$ & 0.945 & $<0.001$ \\
\hline
\end{tabular}

$\mathrm{y}$ - equation of linear regression; $\mathrm{R}$ - correlation coefficient; $\mathrm{P}$ - significance of correlation 


\section{Discussion}

An advantage of venous blood collection for the measurement of acid-base balance is the ease of sampling. However, it enables us to evaluate mostly its metabolic component. Venous $\mathrm{pH}$ may be lower by 0.05 or more than the $\mathrm{pH}$ of arterial blood, which is flowing towards tissues and cells of the organism. The need to collect arterial blood for laboratory diagnostics is related to the possibility of a more complex evaluation of acid-base balance, particularly the assessment of blood gases, supply of tissues with oxygen, and primary and secondary disorders of the respiratory tract in various pathological states leading to hypoxia and hypercapnia in the body.

Regarding the importance of evaluating the acid-base balance and blood gases in arterial blood, many clinicians have investigated suitable techniques for collection of arterial blood from animals. These techniques should ensure reliable collection, minimal handling and adverse responses of animals. Simultaneously, they should be safe both for the animal and the surgeon. On the basis of the verified techniques for substituting arterial blood with arterialised capillary blood in human medicine, there were attempts to use such techniques also in animals. While these techniques are quite well developed in dogs (Sharpe et al., 1968; Sandmann et al., 1983), the collection of arterialised blood in horses and cattle is not widely used. Verhoeff and Wierda (1983) studied the use of arterialised blood, instead of arterial blood, in the assessment of acid-base balance and blood gases in calves. They based their study on the assumption that arterial blood collection in cattle requires sufficient experiences and skill, and, moreover, represents some risk for both animals and humans. They compared the indices in arterialised blood obtained after a small incision in the auricle edge with the arterial blood from the $a$. brachialis. They reported high significant correlation of $\mathrm{pO}_{2}$ and actual bicarbonate. On the other hand, values of $\mathrm{pCO}_{2}$ and $\mathrm{pH}$ showed larger differences and a lower correlation of individual reports. As a probable cause of these differences the authors suggest the possible admixture of venous blood, the insufficient arterialisation of the incision site, as well as the contamination of the samples with air.

Because of the aforementioned factors, several authors looked for the most accessible arteries in cattle and for collection methods involving direct vessel puncture. Among numerous arteries, some were selected and used for direct puncture. In the clinical practice, because access to central arteries is frequently difficult due to their deeper localisation, collection from peripheral arteries, especially from the a. auricularis, is preferred (Riley and Thompson, 1978). Some authors analysed paired samples of arterial blood collected from larger central (mostly the $a$. carotis communis and the $a$. brachialis) and smaller peripheral arteries (the $a$. coccygea and the $a$. auricularis caudalis) including comparison of acid-base balance variables and blood gases. However, not the same sampling 
methods were used in all studies. For example, the use of a catheter for collection from the a. carotis (Oakley et al., 1980; Gustin et al., 1988) or the puncture of the a. auricularis after preceding local anaesthesia (Oakley et al., 1980).

The results achieved in these studies were not entirely consistent. In calves, Oakley et al. (1980) found relatively small site differences of $\mathrm{pH}, \mathrm{BE}$, $\mathrm{pO}_{2}$, and sat $-\mathrm{O}_{2}$ (the $a$. carotis $v$ s. the a. auricularis) with trends similar to those found in this work. However, the average values of $\mathrm{pCO}_{2}$ and bicarbonates were higher in samples from the a. carotis than from the a. auricularis. Moreover, the authors did not present a statistical evaluation of the results and a correlation of individual values. Fischer et al. (1980) compared arterial blood from the $a$. brachialis and the a. auricularis in cattle 10 months to 6 years old. They found a nonsignificant correlation of $\mathrm{pH}, \mathrm{pCO}_{2}$, and $\mathrm{HCO}_{3}{ }^{-}$and significantly lower values of $\mathrm{pO}_{2}$ (with a correlation of 0.84 ) in the peripheral blood. The aforementioned authors suggested that the tendency to lower $\mathrm{pO}_{2}$ values in arteries distant from the heart might be caused by the smaller regions supplied by these arteries. Before the arterial blood reaches these regions distant from the heart, it may lose some oxygen. Different results in calves have been reported by Gustin et al. (1988). They reported a highly significant correlation between individual values of $\mathrm{pH}, \mathrm{pCO}_{2}, \mathrm{HCO}_{3}^{-}$, as well as $\mathrm{pO}_{2}$, in paired blood samples collected from the a. carotis and the $a$. coccygea. They concluded that it is possible to collect arterial blood from the $a$. coccygea. However, there is a need to avoid the admixture of venous blood. Collie (1991) reported similar results when he compared the variables of blood collected from the $a$. brachialis and the a coccygea. He found significant correlation of $\mathrm{pH}, \mathrm{HCO}_{3}^{-}$, and $\mathrm{pO}_{2}$; however, contrary to the aforementioned studies, individual $\mathrm{pCO}_{2}$ values did not correlate significantly. According to the author, it is impossible to explain these differences physiologically. They probably reflect the relatively small numbers of samples (10-14) and the effects of the sampling technique, i.e. the restraining of animals, the time between collection and analysis, the storing and transport of samples, the admixtures of venous blood, and air bubbles due to incorrect sampling. All of these factors may contribute to false results (Haskins, 1977; Poulsen and Surynek, 1977; Szenci et al., 1991; Szenci et al., 1994).

The results presented showed a high and significant correlation in all the variables investigated and correspond to the results of Gustin et al. (1988). Compared with the results of Fischer et al. (1980), we found higher and significant correlation in all variables. Contrary to the studies cited, our results were obtained from a larger group of animals and indicate the degree of possible differences in case of peripheral arterial blood analysis. Despite statistically significant differences between the sampling sites in our work, from the biological and clinical point of view, we consider these differences as practically not important. On the basis of our results, to evaluate acid-base balance and blood gases we consider the sampling method and examination of peripheral arterial blood pre- 
sented as more suitable and reliable than the examination of venous blood. First of all, it is related to blood gases, which are primarily the most susceptible to various extravital influences. With sufficient skill and practice, it is possible to use the sampling of peripheral arterial blood as an adequate substitute for central arterial blood collection.

\section{References}

Adams, R., Holland, M. D., Aldridge, B., Garry, F. B. and Odde, K. G. (1991): Arterial blood sample collection from the newborn calf. Vet. Res. Commun. 15, 387-394.

Alnoor, S. A., Slocombe, R. F., Derksen, F. J. and Robinson, N. E. (1986): Hemodynamic effects of acute pneumonia experimentally induced in newborn calves inoculated with Pasteurella haemolytica. Am. J. Vet. Res. 47, 1382-1386.

Bajcsy, Á. Cs., Bartyik, J. and Szenci, O. (1999): Comparison of blood ionized calcium and acidbase variables in samples obtained from different sampling sites in dairy cows. J. Vet. Med. A, 46, 255-259.

Becker, M. (1977): Eine Methode des arteriellen Zugangs beim Rind. Schweiz. Arch. Tierheilk., 119, 193-195.

Collie, D. D. S. (1991): Blood gas and acid-base values in calves, sampled from the brachial and coccygeal arteries. Br. Vet. J. 147, 232-237.

Deegen, E. (1983): Beurteilung von Blutgasparametern des arteriellen Blutes bei Pferden mit respiratorischen und metabolischen Störungen. Prakt. Tierarzt, Coll. Vet. XIV, 128-132.

Donawick, W. J. and Baue, A. E. (1968): Blood gases, acid-base balance, and alveolar-arterial oxygen gradient in calves. Am. J. Vet. Res. 29, 561-567.

Feigl, E. O. and D'Alecy, L. G. (1972): Normal arterial blood pH, oxygen, and carbon dioxide tensions in unanesthetized dogs. J. Appl. Physiol. 32, 152-153.

Fischer, E. W., Sibartie, D. and Grimshaw, W. T. R. (1980): A comparison of the $\mathrm{pH}, \mathrm{pCO}_{2}, \mathrm{pO}_{2}$ and total $\mathrm{CO}_{2}$ content in blood from the brachial and caudal auricular arteries in normal cattle. Br. Vet. J. 136, 496-499.

Gustin, P., De Groote, A., Dhem, A. R., Bakima, M., Lomba, F. and Lekeux, P. (1988): A comparison of $\mathrm{pO}_{2}, \mathrm{pCO}_{2}, \mathrm{pH}$ and bicarbonate in blood from the carotid and coccygeal arteries of calves. Vet. Res. Commun. 12, 343-346.

Haskins, S. C. (1977): Sampling and storage of blood for $\mathrm{pH}$ and blood gas analysis. J. Am. Vet. Med. Assoc. 170, 429-433.

Lieske, R., Deegen, E. and Fischer, J. (1981): Der Einfluss der Lagerungstemperatur und -dauer auf das Verhalten einiger Blutgasparameter im arteriellen Pferdeblut. Prakt. Tierarzt 62, $477-480$.

Muylle, S., Anthone, P., Simoens, P. and Lauwers, H. (1996): Preferential sites for arterial blood sampling in cattle. Vet. Rec. 139, 86-88.

Nagy, O., Kováč, G., Seidel, H., Michna, A. and Paulíková, I. (1999): Experiences with collection of arterial blood in cattle. Proceedings of the $1^{\text {st }}$ Middle-European Buiatrics Congress, Balatonfüred, Hungary, pp. 109-111.

Nagy, O., Šedovič, M. and Slanina, L. (1994): Central and peripheral arterial and venous blood in cattle with respect to acid-base balance evaluations. Vet. Med. Czech 39, 1-9.

Naito, Y. and Murakami, D. (1982): Blood gas and acid-base values in the coccygeal artery of Holstein-Friesian cows. Jap. J. Vet. Sci. 44, 777-780.

Oakley, G. A., Jones, D. E., Harrison, J. A. and Wade, G. E. (1980): A new method for obtaining arterial blood samples from cattle. Vet. Rec. 106, 460.

Poulsen, J. S. D. and Surynek, J. (1977): Acid-base status of cattle blood. Sampling and storing. Nord. Vet.-Med. 29, 271-283. 
Quandt, J. E., Raffe, M. R., Polzin, D., Robinson, E. P. and Mandsager, R. E. (1991): Evaluation of toenial blood samples for blood gas analysis in the dog. Vet. Surg. 20, 356-361.

Riley, J. H. and Thompson, J. R. (1978): Anaerobic arterial sampling technique in the bovine species. Am. J. Vet. Res. 39, 1229.

Sandmann, H., Nolte, I., Bonath, K. and Failing, K. (1983): Eine methode der kapillären Blutgewinnung beim Hund für die Messung der Blutgase und des Säure-Basen-Status. Kleintierpraxis $\mathbf{2 8}, 75-87$.

Sharpe, J. J., Nelson, A. W. and Lumb, W. V. (1968): Estimation of arterial acid-base values from toenail blood of the anesthetized dog. Am. J. Vet. Res. 29, 2365-2369.

Szenci, O., Brydl, E. and Bajcsy, Á. Cs. (1991): Effect of storage on measurement of ionized calcium and acid-base variables in equine, bovine, ovine and canine blood. J. Am. Vet. Med. Assoc. 199, 1167-1169.

Szenci, O., Németh, F., Stollár, Zs. and Brydl, E. (1994): Effect of storage time and temperature on ionized calcium concentration in bovine and ovine blood, plasma and serum. J. Am. Vet. Med. Assoc. 204, 1242-1244.

Trim, C. M. (1980): Method for obtaining arterial blood samples. Vet. Rec. 107, 265.

Uhling, A. and Gorzny, O. (1993): Blutgasanalytische Untersuchungen bei lungengesunden Mastkälbern unterschiedlichen Alters. Mh. Vet. Med. 48, 255-259.

Verhoeff, J. and Wierda, A. (1983): Use of blood from arterialised capillaries in the ears of calves for the analysis of $\mathrm{pO}_{2}, \mathrm{pCO}_{2}, \mathrm{pH}$ and bicarbonate. Res. Vet. Sci. 35, 124-126.

Vestweber, G. E., Guffy, M., Kelly, B. and Leipold, H. W. (1977): Chronic bronchopneumonia in cattle. The Bovine Pract. 12, 55-62.

Waizenhöfer, H. and Mülling, M. (1978): Untersuchungen über das Verhalten von $\mathrm{pH}_{\mathrm{akt}}, \mathrm{pO}_{2}$ und $\mathrm{pCO}_{2}$ in venösen, kapillären und arteriellen Blut neugeborener Kälber. Berl. Münch. Tierärztl. Wschr. 91, 173-176.

Weber, O., Reinhold, P., Steinbach, G. and Lachmann, G. (1992): Methodische Untersuchungen zur transmukosen Sauerstoffpartialdruckmessung an Kalb und Hund. Berl. Münch. Tierärztl. Wschr. 105, 267-271. 